\title{
Subjectivity and the Obliteration of Meaning: Contemporary Art, Activism, Social Movement Politics
}

Alex Flynn

Durham University, $\mathrm{UK}^{1}$

\begin{abstract}
In this article I analyse the notion that social movement politics and contemporary art interventions increasingly traverse a porous boundary, be it in terms of practices, relations, or institutions. Premised on Nicolas Bourriaud's seminal reading of 1990s art, I contend that the theory of "relational aesthetics" (2002) offers a synthetic platform from which we can understand how artistic interventions with activist connotations are increasingly moving away from the utopian and prescriptive, and thus echoing the "subjective turn" of social movement politics more widely. Based on fieldwork with contemporary artists and social movement actors in Brazil, the chapter mobilises relational aesthetics as a criteria to differentiate various forms of contemporary art intervention. Through conversation with ethnographies of radical politics, I argue that an analysis that foregrounds ephemerality, the "absolute centrality of diversity", and different forms of dissonance, allows us to productively theorise how subjectivity is elaborated and meaning created. If art really is the locus of "imminence", then understanding how these processes are contested is to grasp how prefigurative politics can have consequences for the immediate future.
\end{abstract}

Keywords: micro-utopia, subjectivity, relational aesthetics, contemporary art, activism, social movements

\section{INTRODUCTION}

Movements such as Occupy and Brazil's Landless Workers' Movement (MST) have placed relational art practices at the heart of calls for change. Equally, artists such as Tania Bruguera

1 Department of Anthropology. Author's contact email: alex.flynn@durham.ac.uk. This article has been supported by funding from the British Academy and Durham University's International Office. I would like to thank my coeditors and the anonymous reviewers for their insights and constructive feedback in revising this article. 
and $\mathrm{Ai}$ Weiwei have put forward an aestheticised political agenda, mobilising institutional spaces to articulate activist concerns. Nestor García Canclini argues that "art is the place of imminence - the place where we catch sight of things that are just at the point of occurring" (2015: xiii). But if we accept that there is an on-going revision of the cartographies of art history and activism, and the dissolution of attendant categories of practice, what implications might this have for what is "just about to occur"? What ramifications might we consider for subjects such as the construction of subjectivity if art with activist connotations is to be taken seriously as an analytical category? Is it the case that analysis situated from the very interstices of overlapping terrains can lead to a productive theoretical contribution?

In this article, I take as an initial premise the idea that social movement actions and contemporary art interventions increasingly traverse a porous boundary, be it in terms of practices, relations, or institutions. Premised on Nicolas Bourriaud's seminal reading of 1990s art, I contend that the theory of "relational aesthetics" (2002) offers a synthetic platform from which we can understand how artistic interventions with activist connotations are increasingly moving away from the utopian and prescriptive, and thus echoing the "subjective turn" (Razsa 2015) of social movement politics more widely. Based on fieldwork with contemporary artists and social movement actors in Brazil, the article highlights that while there is an on going collapse of categories between contemporary art interventions and social movement actions, these diverse political art experiments are not all equivalent: some may open spaces for encounters between different subjectivities, while others may delimit the potential of such encounters, rendering the elaboration of meaning less open a process. Relational aesthetics here offers important criteria with which to differentiate such projects and in this manner productive points of comparison emerge regarding how subjectivity is elaborated and meaning created, and in what temporal framework.

I begin by discussing the influence of social movement theory on artistic practice before tracing this influence to the "subjective turn" in social movement politics. In connecting these fields, I draw attention to the subjective turn's perspective on the utopian and its focus on both subjectivity and participatory decision-making. I then elaborate the theoretical framework of this article, placing relational aesthetics in conversation with an ethnography of radical politics, foregrounding the importance of actors' subjectivity as opposed to the setting in which such subjectivities are supposedly created. This theoretical framework encompasses a discussion on dissonance and I highlight how both the MST and the contemporary art world in São Paulo engage with identity politics, before moving to the article's principal ethnography - the contemporary art intervention, Jardim de Passagem. The contrasting intentions of these examples demonstrate how for both social movements and politicised art experiments the elaboration of meaning is keenly contested, a discussion I expand through an analysis of Claire Bishop's critique of relational aesthetics and her counter proposal, "relational antagonism". I conclude by suggesting that if art really is the locus of imminence it is to the open-ended and subjective rather than the identitarian that we should turn our attentions.

\section{Definitions}

Before moving to the first section of this article, I would like to offer working definitions of key terms. Meaning here is understood in everyday terms as what is intended to be, or ac- 
tually is, expressed or indicated. However, the elaboration of meaning, which is central to this article, refers to the process by which subjective interpretations of phenomena are contested by multiple persons. In a 1957 lecture, Marcel Duchamp argued that:

The creative act is not performed by the artist alone; the spectator brings the work in contact with the external world by deciphering and interpreting its inner qualification and thus adds his contribution. (Lebel 1959: 77)

In the interventions that this article analyses, a similar, multiple, and contested elaboration of meaning takes place, pertaining to such notions as free speech, democracy, agrarian reform, public space, or citizenship. The possibility of an obliteration of meaning arises as these processes may be variously left more open or closed to the subjective interpretation of their participants. My intention here is not to build specifically on a post structuralist understanding of meaning: Barthes refuted the "unity" or "totality" of a text, in preference for a fragmentary intertextuality, thus denying stable categories and unitary meaning. But in the examples I put forward, obliteration has more to do with the means and possibility of articulating one's subjectivity, as opposed to a Derridean obliteration of "oppositions" or even the idea that writing in and of itself is the moment of any given author's "obliteration".

Duchamp termed this vector the "art coefficient": the difference between "the intention and its realization" on the part of the artist regarding any proposition. This coefficient, as an "arithmetical relation between the unexpressed but intended and the unintentionally expressed" (ibid: 77) may be low or high, and in this variance, it represents the extent to which the person proposing an intervention has control over the meaning that can be imparted, a key point that I wish to examine in this article. In this sense, the obliteration of meaning is more fully the idea of the removal of the possibility to elaborate your own meaning from within a relational process: a series of closed gestures in which the fundamental condition for intersubjectivity, the participation of multiple subjects, is no longer fulfilled.

Meaning in this sense is elaborated by multiple subjects, each with his/her own subjectivity. This focus on subjectivity characterises research on the "subjective turn", an analytical approach that Maple Razsa has initiated. In this article, I seek to provide ethnographic evidence of the importance of such an approach, building on the work of such scholars as Jeff Juris and Marianne Maeckelbergh, but focusing less on organisational activities, in favour of an analysis that foregrounds the role of individual subjects in contemporary artistic/activist interventions. A clear understanding of subjectivity is central therefore to this article.

In a philosophical sense, subjectivity, through perception, experience and apprehension of phenomena, is constituent of consciousness. As the possession of conscious experiences is a precondition for a subject, subjectivity not only defines what it is to be an individual, but also shapes his/her actions on objects beyond that immediate conscious space, as these experiences and/or phenomena have a direct bearing as to how that individual perceives subjective reality. Anthropological research on subjectivity has ranged from questions of diasporic identity (Brodwin 2003), violence and gender (Das 2008), the Palestinian Intifada (Jean-Klein 2000), but also how subjectivity can be thought of as a semiotic construct (Leone 2013). And it is connected to this idea of subjectivisation through semiotics that Félix Guattari's theory of subjectivity provides the principal intellectual grounding of this article. Transforming Lacan's conception of subjectivity as decentred and incomplete, and specifically expanding the Lacanian notion of "partial object", Guattari puts forward the following definition: 
The ensemble of conditions which render possible the emergence of individual and/or collective instances as self-referential existential Territories, adjacent, or in a delimiting relation, to an alterity that is itself subjective. (1995: 9)

Subjectivity for Guattari, as Simon O'Sullivan states, is therefore "collective and specifically relational' (2012: 258 my emphasis). And what is particularly pertinent about Guattari is his foregrounding of art (an ethico-aesthetic instance) in the process of subjectivisation:

According to Bakhtin, in this movement the 'consumer' in some way becomes co-creator; the aesthetic form only achieving this result through the device of an isolating or separating function of such a kind that the expressive material becomes formally creative. (Guattari 1995: 14)

Guattari here echoes Duchamp's "art coefficient" and in this manner brings together the two key concepts of this article into a cohesive intellectual paradigm.

\section{Contemporary art interventions}

The Occupy movement's impact on the contemporary art world is just one instance of a growing preoccupation with what has variously been termed social, participatory, or activist art. The coalescence of Occupy Wall Street inspired the contemporary art journal "October" to dedicate an entire issue to a discussion of the movement's politics, and Occupy's practice echoes so much of the recent curatorial lexicon that a new journal, FIELD, has been established specifically to focus on "socially engaged art criticism". In his introductory text, editor Grant Kester writes that FIELD was created in response to "the remarkable proliferation of contemporary socially engaged art over the past fifteen years" (2015: 1) and one of the most important epistemic sites for this type of knowledge production has been the contemporary art biennale. Ever more participatory and focused on research processes as opposed to the "art object", the biennale has become a privileged space of encounters from which to explore the emancipatory potential of art. Panos Kompatsiaris (2014: 80) writes of this desire to link art to urgent realities:

The third Athens Biennale wishes to "transform the biennale into a sit-in and a gathering of collectives, political organizations and citizens involved in the transformation of society, an invitation to create a political moment rather than stage a political spectacle". In turn, the curator of the 7th Berlin Biennale, Artur Zmijewski, calls the invited artists to "identify their political positions" and describe what they are doing as artists "also in pure political terms". The 12th Istanbul Biennale seeks to "explore the relationship between art and politics, focusing on works that are both formally innovative and politically outspoken", while the 2012 Manifesta edition focuses "on aesthetic responses to the worldwide 'economic restructuring' of the productive system in the early 21 st century".

This activist stance stems from a wider resistance to perceived hegemonic neoliberalisms that recurs throughout the political ecology of the contemporary art world. The award of art prizes offers an important indication of the direction of travel in this sense: influential institutions such as the European Cultural Foundation (ECF) for example have directed resources and prestige to politicised interventions through annual awards. Since 2012, ECF award laureates have included the Teatro Valle Occupato, Teodor Celakoski, and Charles Esche. Of the Teatro Valle and Celakoski, jury member and current director of Tate Modern, Chris Dercon, stated, "it is precisely the precarious conditions felt by countries hardest hit by the financial crisis that Teodor Celakoski and the collectives he works with and Teatro Valle Occupato are trying to address and to overcome", while Esche was praised for his promotion of a "conversa- 
tion that imagines how individual citizens can live and enact a future society together". The ECF has praised their laureates specifically for the way in which they "show us how collective forms of action can tangibly influence a wider civil sphere" and their award for 2016 further reflects this approach:

Athens Biennale has re-imagined the model of the biennale as a space for cultural debate and grassroots organising in contemporary Greece. It has reinvented the art biennale as a structure that enables new forms of solidarity between local and international cultural communities and wider civic engagement. ${ }^{2}$

The implicit and explicit lexicons of "collective forms of action" and "grassroots organising" are deeply reminiscent of social movement terrain and these porous boundaries have been analysed among others by Néstor García Canclini (2015). In his analysis García Canclini highlights how art practice is increasingly expanding into sectors of urban development, design and tourism industries. Pointedly, Canclini argues that art is "even being asked to take the place once filled by politics by providing collective spaces to deal with intercultural relations" (2015: xi). As such, for García Canclini: "Art processes are epistemological places where art and society, aesthetics and sociology, rethink their ways of making and knowing" (2015: 162). ${ }^{3}$

\section{Artivism}

The collapse of boundaries signified by the proliferation of social, participatory, or activist art has thus instigated not only new knowledge categories, but also an art historical container in which to place them. Broadly termed as "artivism" (Sandoval and Latorre 2007, Asante 2009), it is important to consider that despite such categorisation, the varied political art experiments that sit within a unitary classificatory system are not all equivalent: depending on the criteria by which they are assessed, some may offer possibilities for encounters between different subjectivities, while others may seek to delimit such intersubjectivity, promoting the transference of a message as opposed to the creation of dialogue.

Liberate Tate have mobilised such an artivist discourse in questioning the Tate's sponsorship by British Petroleum (BP). Their protests, which enter into dialogue with existing aesthetic regimes and are art works in and of themselves, point not only to the tensions inherent to such artivist practice, but also to how such interventions have prompted questions of institutional critique. In 2012, as part of the performance "The Gift", a wind turbine blade was submitted to the Tate under the rubric of a "gift to the nation", a gift which the Tate's curatorial board ultimately rejected. ${ }^{4}$ However, as Mel Evans notes, although the Tate rejected the art object, "performance documentation of 'The Gift' is held in Tate's archive" (2015: 163), thus emphasising the interstitial position of groups like Liberate Tate and artivism more widely. It is unclear whether being included in the archive, as opposed to the permanent collection, is a slight, or a

2 All quoted ECF text available on the ECF website: http://www.culturalfoundation.eu/pma/, accessed 20 October 2015.

3 Canclini's analysis of the expansion of art world beyond traditional spheres is occurring despite, or perhaps because of, its self-referential structures of power and decision-making. In this manner, cultural foundations give awards to biennales, biennales are curated by cultural foundation laureates, (Charles Esche, São Paulo 2014), and jury members offer pronouncements on social movements occupying biennale space: Chris Dercon on the Occupy movement at the $7^{\text {th }}$ Berlin biennale: "there was not much to see" (Farrington 2013).

4 See the following for video and documentation: http://www.liberatetate.org.uk/performances/the-gift/, accessed 21 October 2015. 
victory; an example of appropriation, or an instance of functioning institutional critique. But the actions of groups like Liberate Tate that position themselves between a social movement and an artistic collective, call into question how institutions react to this type of artistic practice and production. ${ }^{5}$

Artivism in this sense seems relatively marginal, but one need only think of recent high profile exhibitions by artists such as Ai Weiwei at the Royal Academy (2015) or Tania Bruguera's Tatlin's Whisper series to understand how aesthetic projects with activist connotations extrapolate at the very core of some of the art world's most conservative institutions. When Jen Harvie can write texts for the Royal Academy declaring that such work "can provide catalyst for change", it is clear that activist vocabulary, and even practices, are beginning to bleed into previously discrete worlds, worlds that include high value cultural and financial capital. ${ }^{6}$ Such engagements can be freighted with ethical implications. Commenting on Ai Weiwei posing as a dead refugee child to recreate an iconic photo, art critic Karen Archey declared: "If we were to ascribe a set of ethics to art engaging activism, I would suggest number one: Do not accept capital gain from restaging images of dead refugee toddlers". ${ }^{7}$

\section{THE SUBJECTIVE TURN IN SOCIAL MOVEMENT POLITICS}

The pervasiveness of such an activist art is intrinsically connected to the spaces, discourses, and social media channels in which a new type of social movement discourse has been articulated. Since the Genoa G8 Summit protest, the collective momentum generated by a wave of social movements such as the alterglobalisation movement, Brazil's Landless Worker's movement (MST), Occupy, the Zapatistas, and the Indignados, has infused theory, practice, and scholarship of social mobilisation with fresh vigour. The actors who participate in these movements seek to change how politics is conducted, but more importantly, generate new ways as to how meaning itself can be created, and it is precisely here, recalling García Canclini's emphasis on how art processes rethink ways of making and knowing, that this article seeks to build an analysis. Building on the school of new social movement theory elaborated by Alan Touraine (1988) and Ernest Laclau and Chantal Mouffe (1985), scholars such as Marianne Maeckelbergh (2009), Jeff Juris (2008), Maple Razsa (2015) and Arturo Escobar (2014) have analysed how this process of envisioning and realising new worlds occurs. In particular, Maeckelbergh has detailed how participatory decision making practices can offer the beginnings of an emerging democratic alternative by placing the diversity of people's subjectivities at the heart of decision making practices. Razsa equally portrays how alterglobalisation actors seek alternative worlds by shunning utopian ends and centralised authority in favour of forms of direct democracy that enact a prefigurative politics. In both analyses, subjectivity emerges as a key site of conflict and creativity as activists independently "seize the means of producing themselves as subjects" (Razsa 2015: 12).

5 Liberate Tate's submission was not accepted by the Tate, but 2 years later many activist objects were displayed in the Victoria and Albert Museum's much praised exhibition "Disobedient Objects", including Artúr van Balen's inflatable cobblestone.

6 Jen Harvie's article for the Royal Academy "Art and activism: can it change the world?": https://www. royalacademy.org.uk/article/ai-weiwei-can-art-change-the-world, accessed 21st October 2015.

7 For photo op, Ai Weiwei poses as dead refugee toddler from iconic image. By Karen Archey. Available at: http:// conversations.e-flux.com/users/karenarchey/activity. 
The theory that underpins what Razsa identifies as a "subjective turn" is in stark contrast to previous approaches to social movement politics, traditionally articulated within sociological scholarship, that sought to explain how and why large groups of people came together to "mobilise". Whether "collective behaviour" (Park 1967), "mob mentality" (Arendt 1951), "rational choice" (Olson 1965) or Marxist studies focusing on class, analyses of collective action have long been premised on functionalist readings that overlook ethnographic realities of context, individuality, and location. A focus on subjectivity allows us to unpack concepts such as "frame alignment" (Snow et al. 1986), or "organisational structure" (Kriesi 1996) and focus on the nuanced ways in which mobilisations are conceived, enacted, and performed. Such a perspective reveals the ephemeral, and highly site-specific nature of how people protest and this shift from a generic terrain of mass-mobilised dissent to what Tilly (2008) terms "ensembles" of smallscale performance, offers a framework in which productive comparisons with activist art installations can be made.

\section{Relational aesthetics as CRITERIA}

In my own research on social movements, I have analysed the political performance of the MST, termed as mistica by members of the movement, from a perspective which foregrounds the private reflective worlds of its participants, as opposed to the organisational structure in which such practices are embedded (Flynn 2015). Central to my analysis has been the theory of relational aesthetics. Put forward by the art historian and curator Nicolas Bourriaud, the relational aesthetic paradigm argues that art has "as its theoretical horizon the realm of human interactions and its social context rather than the assertion of an independent and private symbolic space" (2002: 14). In this manner, artworks, or, in the case of the MST, performances of mistica, are capable of producing "micro-utopias", temporary communities of intersubjective encounters in which people can "invent democratic relations with our neighbours" (ibid: 45) from within a space that allows for a full range of diverse subjectivities. Relational aesthetics thus foregrounds the notion that "viewers" of art works are in fact active "participants", invited by a wider collective to elaborate tropes of meaning: a work of art in this sense becomes a "social form", political in implication and emancipatory in effect.

Unlike other readings of mistica, which depart from a more organisational point of view, highlighting for example the form's emancipatory (Issa 2007), pedagogic (Hammond 2014, Tarlau 2013), or community building potential (Wolford 2003), the framework of relational aesthetics makes possible a reading of mistica as a site through which members of the MST can articulate diverse political subjectivities, and importantly, create meaning that may be divergent from any given performances' intended "pedagogic" message (Flynn 2013, 2015). In an analysis that seeks to demonstrate mistica's potential to allow members to "seize the means of producing themselves as subjects", I argue that there is a nuanced and deliberately ambivalent discrepancy between creating a reflexive and artistic gesture towards an audience (a performance of landlessness) and articulating one's own transformation through this gesture (a performative act), a discrepancy which highlights the marked ethico-aesthetic dimensions to mistica: members take stock of where they are, and imagine possible futures that may differ from the MST's wider vision. 
One might suggest at this point that in terms of the form's focus on "producing subjects", there is little difference between my analysis and that of previous, more classically Marxist readings. However, the emphasis that Bourriaud places on the temporality of the micro-utopia is significant. The spaces of community that relational art works can generate are transient and as such point to a key provocation as regards social mobilisation.

The age of the New Man, future oriented manifestos, and calls for a better world all ready to be walked into and lived in is well and truly over. These days utopia is being lived on a subjective, everyday basis, in the real time of concrete and intentionally fragmentary experiments. The artwork is presented as a social interstice within which these experiments and these new 'life possibilities' appear to be possible. It seems more pressing to invent possible relations with our neighbours in the present than to bet on happier tomorrows. (2002: 45)

The lack of conviction in utopian solutions that characterises relational aesthetics is mirrored in the politics that underpin the subjective turn in social movements more widely. Razsa points to how although alterglobalisation actors seek alternative worlds, unlike previous movements, they shun utopian ends and centralised authority in favour of forms of direct democracy to enact a prefigurative politics. A further point in common between the two platforms is the temporal aspect: artistic interventions made by social movements can be read as spaces of micro-utopia as they are necessarily interventions into volatile situations. However, if meaning really is the central concern of projects characterised by relational aesthetics and interventions proposed within the "subjective turn", then it is necessary to ask how such processes are contested, and if how do we understand the inevitable dissonance that is created?

\section{UNDERSTANDINGS OF DISSONANCE}

In his discussion of the artist Felix Gonzalez-Torres, Bourriaud notes how already in the early 1990s Gonzalez-Torres was articulating a paradigm for a more nuanced practice regarding the interstices between politics and aesthetics. For Gonzalez-Torres, himself heavily involved in the gay rights movement, the manner in which he created his work hinged on a certain openness of interpretation, an interstitial space through which people could create their own meaning. Bourriaud calls attention to Gonzalez-Torres' comment on his work "Untitled" (Perfect Lovers), 1987-1990:

Two clocks side by side are more of a threat to power than the image of two guys giving each other a blowjob, because [systems of power] cannot use me as a rallying point in [their] struggle to obliterate meaning. (2002: 56)

Gonzalez-Torres articulates a type of art with activist connotations that leaves subjectivity in the hands of the beholder rather than furnishing slogans and prêt-à-porter calls for change. This hints towards a type of political articulation that does not prompt responses that "obliterate meaning" but rather invites dialogue without recourse to sloganeering. For Gonzalez -Torres, positioning two clocks side by side is a celebration of gay union, but the aesthetic juxtaposition does not allow people to take "offense" at a more "explicit" image. In this way, a spectator who might describe him/herself as "morally conservative" is neither afforded an easy way out of contemplating gay sex, nor a faux sense of moral outrage with which to dismiss wider issues connected to the LGBTI platform. 


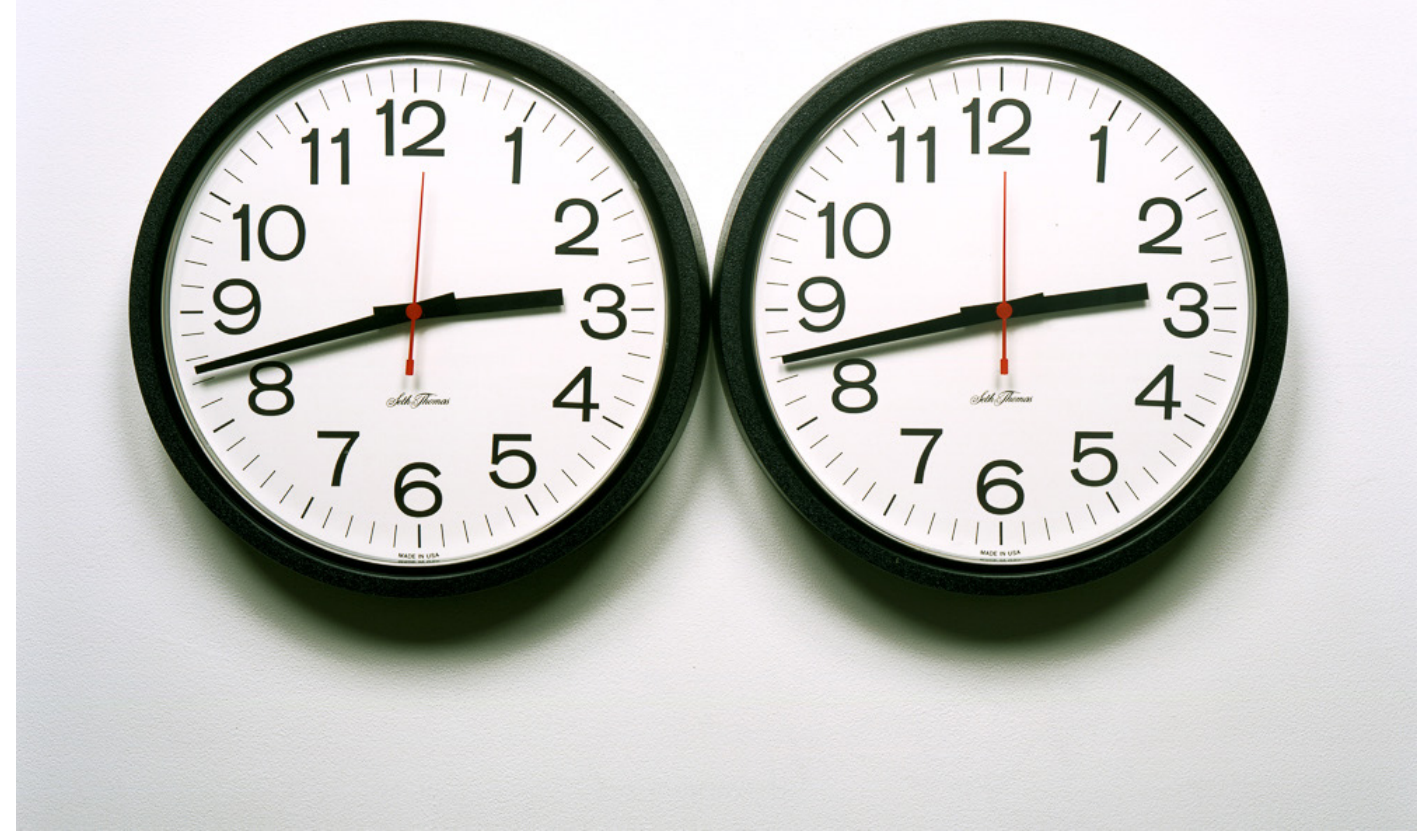

Felix Gonzalez-Torres, "Untitled" (Perfect Lovers), 1987-1990. (C) The Felix Gonzalez-Torres Foundation. Courtesy of Andrea Rosen Gallery, New York.

The paradigm advocated by Gonzalez-Torres' aesthetic decisions clearly resonates with how social movements characterised by the subjective turn have moved beyond identity politics to recognise difference in their members and integrate that difference as a key part in their calls for change. For Gonzalez-Torres, being gay represented "not so much a proprietary discursive theme, than a universally accessible emotional dimension" (Bourriaud 2002: 50) and this dimension is not mobilised to reinforce membership of a certain community: quite to the contrary, the celebration of his partner's life and their union becomes a "life model that could be shared by all, and identified with by everyone" (Ibid.).

The inclusive tone inherent to the work of Gonzalez-Torres echoes a social movement politics premised on the "absolute centrality of diversity" (Maeckelbergh 2009: 20). For Maeckelbergh, identity politics was an important phase of social mobilisation, but activists became trapped by the need for political unity and a homogenous identity, resulting in fixed and predetermined subjectivities:

It is no longer identity politics because some shared identity is not the basis upon which alterglobalisation actors are demanding recognition. Rather than insisting that the movement should not focus on the WTO because it is not the quickest means of achieving women's liberation, the fight against the WTO is carried out while incorporating an awareness of the power hierarchies that exclude women, not only from the WTO, but also from the movement. (Ibid.)

Not requiring all movement actors to fit a predetermined identity naturally leads to dissonance and Maeckelbergh highlights how important these dimensions of conflict are in the horizontal elaboration of subjectivity. For these movement actors, "consensus" has come to be rejected through its associations with compromise and unanimity, deeply problematising 
Rawlsian ideas of an "enduring unity". However, the notion that it is an individual's prerogative to express dissonance in whichever way she/he chooses is incorrect. In an analysis of how conflict manifests itself, Maeckelbergh points to two separate dimensions of conflict, constructive and adversarial:

Diversity leads to conflict, it is true, but adversarial conflict is not caused by this flow of diversity, instead it arises when these flows are blocked. Conflict can be productive if it is given space for expression. Nurturing the constructive power and limiting the adversarial power of conflict requires continuous work. (2009: 137)

As I seek to make clear, there is a diversity of contemporary art interventions and these varied political art experiments are not all equivalent: some open spaces for encounters between different subjectivities, while others close off such encounters.

Within the contemporary art world, just as within social movements, politicised interventions with aesthetic dimensions mobilise a range of approaches, from the identitarian, and its attendant consequence, the flattening of subjectivity, to experiments that are more open to reflexivity and individual subjective interpretation. In São Paulo it is common to hear groups of artists who consider themselves "political" demanding a more radical and confrontational relationship between aesthetics and politics. Tied to the phrase, "uma nova geração de artistas jovens" - a new generation of young artists, this identitarian politics can presuppose a manner of how "politics" should be defined, leaving other artists uncomfortable. One artist commented to me that "if we are to go along with his line of thinking, then I think my next work will have to be an installation consisting solely of guns", while another practitioner drily remarked over a coffee, "If we're really going to change everything, then what are we supposed to do, take up arms?" This identitarian discourse evokes a scheme of politics very much distant from the practices of participatory democracy and ideals of prefigurative politics. It perhaps hints that there is a disconnect between a new type of social movement politics premised on diversity and resultant artistic interventions, and more traditional "politicised art", as put forward by contemporary art practitioners, operating within more traditional spheres. ${ }^{8}$

These factions within the São Paulo contemporary art scene follow in a long tradition: attempts to block "flows" of diversity are not a recent phenomenon. As Duchamp's concept of the art coefficient makes clear, the form of an artwork is of singular importance in the transmission of its content. Form is indivisible from the "unexpressed but intended" that will be shared with the spectator, or participant. This connection helps to explain the emphasis with which Marxist organisations have long sought to create and maintain a unitary artistic style, seeking to limit diversity and a supposed fragmentation of the struggle. The Italian Communist Party post World War II is a typical example. Seeking to homogenise artistic activity and anchor it in social realism, a form that would facilitate a clearer message, artists including Pietro Consagra and the editor Elio Vittorini who insisted on "stylistic diversity and individual expression" (Dossin 2015: 23) were excluded from the party. Further decisions on form were delegated to a "cultural commission" in charge of "verifying the conformity of cultural and artistic production" (ibid.).

What is important to highlight is that the practice of attempting to contain dissonance occurs in both contemporary art interventions and social movements. With regards to the

8 It should be noted here that artists in São Paulo are influenced by contemporary realities: events that I attended where these opinions were aired occurred shortly after millions of people in Brazil had taken to the streets either wearing red in support of the government, or yellow and green in a broadly conservative movement of protest and indignation. 
MST, I have argued elsewhere that culture sector leaders emphasise mistica's power to create moments of collective unity rather than its potential to engender powerful dimensions of ethical self-cultivation (Flynn 2013). One reason for this tendency is that mistica is a key locus for the formation of the sem terra (landless) identity, and while members are free to interpret a performance in the manner of their choosing, there is much less possibility to be able to create performances that differ from a standard repertoire. In this way, I describe how Tais, a member of the MST, was prevented from putting forward her own subjective interpretation of mistica. Choosing to rethink a typical mistica performance, she attempted to articulate the concept of landlessness through a belly dance. After MST leaders considered her proposal, it was decided that she could not perform the dance and her performance was censored on the basis that it was considered too vulgar. Soon after this censure, Tais left the movement and the blocking of these "flows" of diversity that Tais experienced is not a unique example in my engagement with the MST. Cristina Chaves (2000) also documents examples of members being expelled from a march to Brasilia. But if dissonance need not necessarily result in obliteration, how might conflict be articulated in a more productive manner? Can contemporary art interventions, diverse as they are, even move social movement theory forward in this respect?

\section{JARDIM DE PASSAGEM}

A question that opens heated political debate in São Paulo is public space. In a city where segregation, violence and aggressive zoning are uncontrolled processes that capture symbolic as well as spatial terrain (Caldeira 2001), interventions that propose a reuse or rethinking of how the city should be accessed and experienced are highly politicised. ${ }^{9}$ Such is the polemical nature attached to questions of access to space, that even placing furniture in a public square becomes a gesture laden with political intent. ${ }^{10}$

It is in this context that I participated in Teresa Siewerdt's intervention, Jardim de Passagem. Siewerdt explores the relationship between one's body and the body of others, and the approximation of that body with wider landscapes. For Jardim de Passagem, 26 performers waited at different bus stops along a specific route, all carrying large plants of different varieties, and waiting for a specific pre-indicated bus. I was the third person to board, and when I did, I sat down unobtrusively towards the back of the long, articulated vehicle. The other two performers were equally as inconspicuous, and fellow passengers didn't seem to find our presence, carrying plants, in any way out of the ordinary. Gradually however, as the bus kept on stopping, and another person carrying a large plant with foliage or exotic blooms came aboard, the murmurs

9 An example of such segregation is the Brazilian shopping, or mall. Privatised spaces for leisure and consumption, they also project a certain class identity through the aestheticised use of building materials such as marble and stone, the presence of air conditioning, parking facilities, and the types of businesses that are tenants of the space. Clearly there is a hierarchy of shopping malls with some being more up-market, and others less so, but security is ubiquitous and complicated micro-readings of your embodied racial and social class positioning may determine whether you are allowed free access, whether you are subject to surveillance, or whether you will simply be denied entry.

10 The Largo da Batata movement aims to render usable a large public space after which the movement is named. After an expensive redevelopment, the space is entirely bereft of any shade, any seating, or any other features that might make it conducive to use. The protest movement puts on classes, parties, builds street furniture amongst other activities to try and highlight the lack of usable public space in São Paulo. See for more information: http:// largodabatata.com.br/a-batata-precisa-de-voce/. 
and laughter began to grow. As the journey continued, there were so many people carrying plants and flowers, that the bus began to resemble a form of mobile garden centre, with hanging baskets suspended on hand rails and the entire bus corridor disappearing behind thick green shrubbery.

Passenger reactions were mixed. The man seated next to me ignored the whole intervention, and by the manner he pushed past me to disembark, seemed perhaps quite annoyed. Another man, due to the sheer amount of plants filling up the space, grew irritated as the foliage from a hanging basket repeatedly poked him in the face. Other passengers, having been initially curious, laughed and smiled once they understood that it was an intervention, and asked what we were doing, saying that the flowers were beautiful. As more and more performers got on board, the atmosphere became ever more light-hearted, and a sense of community sprang up, not just between the 26 performers, most of whom had not previously met each other, but also between the performers and fellow passengers with whom we conversed freely. This nascent sense of community was playful and unexpected, given that we had been directed to not specifically open conversation, but clearly not everyone wanted to participate: the bus journey was in the early afternoon and there were people who just wanted to get home, or listen to music through headphones.

As we neared the bus terminal where the intervention was to end, people begin to ready themselves to disembark. In front of me, I watched as one of the performers chatted with a fellow passenger. We had been directed to offer our plants as a gift to passengers at the end of the journey and the performer in front of me, having struck up a conversation, now offered her plant as a gift.

[1] Would you like to take care of it [the plant]?

[2] I would! I would... Thank you, thank you! It's so beautiful...

The woman who accepted the plant was in tears as they hugged and at this point of emotional connection, there was a sense of the tangibility of the community that had been created as a result of 26 plants and a bus ride from one terminal to another. As we all got off the bus, passengers and other people passing through the terminal accepted the plants that we, the performers, were giving away. After the intervention had ended and the bus had left, all that remained was the busy terminal, into which people carrying plants were rapidly disappearing as we, the 26 performers, left for a public/private space, the Praça Victor Civita ${ }^{11}$ to discuss how we felt the intervention had gone. Shortly after this discussion we all went our separate ways.

Jardim de Passagem is perhaps best characterised by its ephemerality. In all, five hours passed between the performers coming together, acquiring a plant and then separating again and very little survives of the intervention. What contrasts with this lack of materiality is the feeling of community that manifested itself in a space that passengers themselves commented was one where conversations rarely occur. The intervention did not try to perpetuate this sense of community: as quickly as relations had been created, they were then left to disperse, without

11 The square was originally a site for the incineration of rubbish until 1989. The space was redeveloped through a partnership between the São Paulo city council and the Abril Group, a major publishing house and media conglomerate in Brazil. The square was eventually named after Victor Civita, one of the most powerful media barons in Latin America and the founder of Abril Group that oversees titles such as Veja, Men's Health, and Playboy. See: http://pracavictorcivita.org.br/conceito/linha-do-tempo/. 
any attempt to engage people beyond that experience. In this manner, no names were written down, or messages exchanged to prolong the state of encounter; the sum of what occurred is video footage that has been compressed into a five minute film, ${ }^{12}$ and a defunct WhatsApp group that the performers used to communicate logistical details. The intervention did not speak to any particular political debate or articulate itself to any kind of slogan. There was no sense that performers were advocating a particular cause, and yet fellow passengers were curious to know what was happening and why. Some passengers said as everyone was getting off that it was nice to speak to someone on public transport; that it was a pleasant change to have a conversation in what was usually such a depersonalised space. Passengers also said they liked the flowers, that São Paulo was a "grey" city and the intervention had made it more colourful.

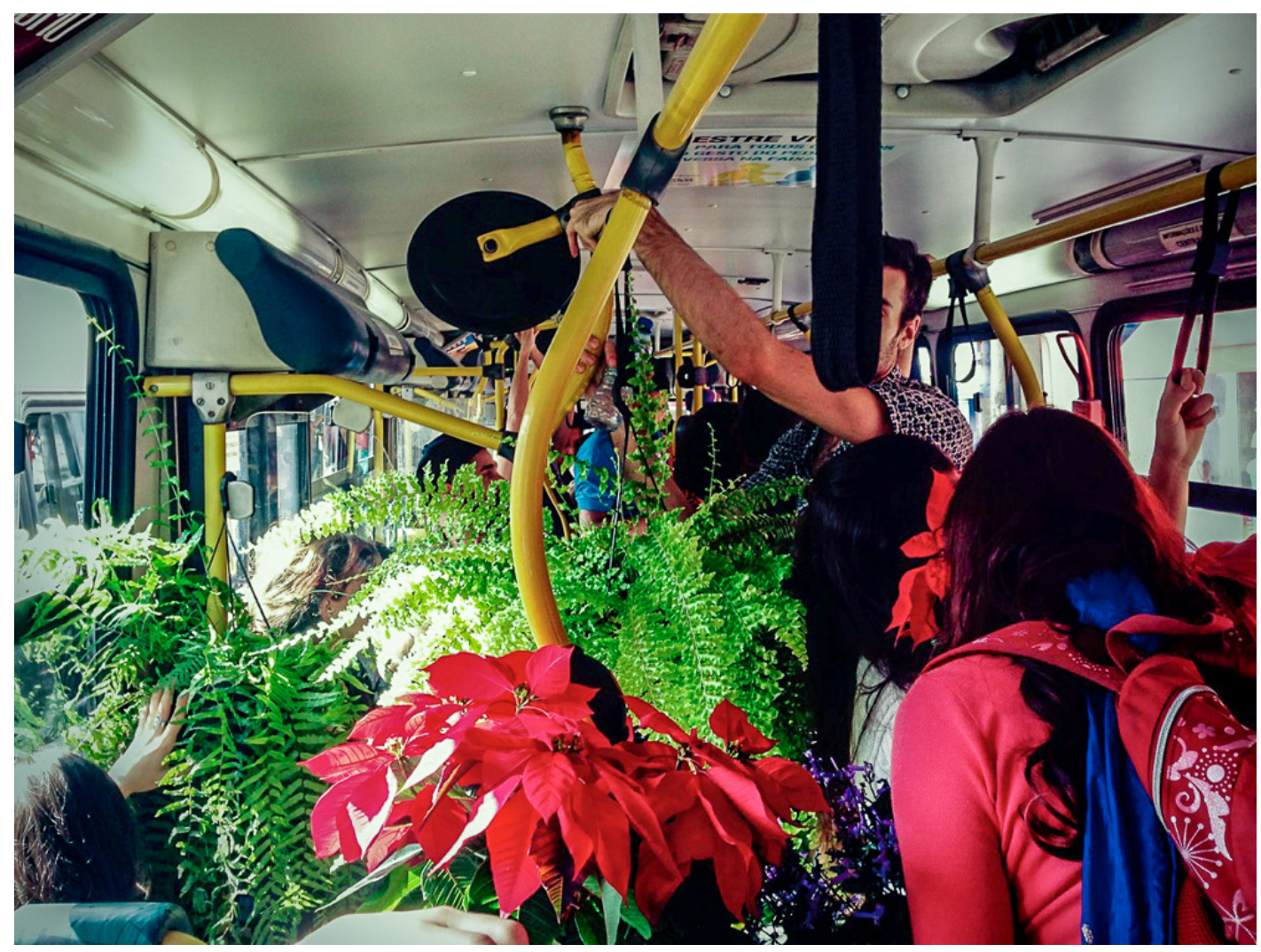

Jardim de Passagem. Photograph by the author.

When I spoke to Siewerdt, some days after the intervention, she shared that she had been apprehensive about how the experiment would unfold. Siewerdt has carried out the intervention twice before, but both times in smaller cities in the interior of São Paulo where as she put it, "people are more likely to chat on a bus". It was her fear that in São Paulo, a busier, and more segregated city, the intervention would not engender forms of exchange or conviviality. From what I observed on the bus, this apprehension was partly realised. There were passengers who resented their commute being interrupted, just as there were passengers who gave no response to the intervention, preferring to remain in their own space. Equally there was a degree of irritation discernible amongst some passengers at what could be considered the "mess", or "inappropriateness" of the situation that was created. But it was the very diversity of passenger reactions

12 For video of the performance Jardim de Passagem see: https://www.youtube.com/watch?v=PNT0f-4DAmc, accessed $21^{\text {st }}$ October 2015. 
that was striking. Some passengers were annoyed, some passengers laughed, interacted and shared jokes, and at least one woman was moved to tears. These ephemeral relations were created as a result of nothing more than carrying a plant and it was precisely the possibility of these relations, as Siewerdt stressed, which had facilitated the open-ended nature of the intervention. For her, the meanings of the intervention rested with the passengers who disembarked, and it was not her role to impose an a priori sense of what the performance was "about". In this openended manner, through a series of deliberately aestheticised intentions, Siewerdt's intervention touched on questions of community, public/private space, and the ephemerality of gestures and relations. In donating the plant at the end of the bus' route, the intervention also pointed to the idea of the gift, and the relations that an object could make possible within the framework of an artistic exchange.

At a seminar I attended a few weeks after the event, there ensued a debate amongst contemporary art researchers as to the "point" of such an intervention. One art scholar asked me to specify what exactly the intervention had changed or brought about. It is my reading that such a question is to mistake the nature of such a project's intention. Within a relational aesthetic paradigm, the liberation of forms of subjectivity takes places within a matrix of horizontality, as opposed to a vertical, authoritarian relationship between artist and audience. In Jardim de Passagem's aesthetic proposition, the determination to not succumb to utilitarian precedents echoes the politics of Guattari in its rejection of a step-by-step transformation of society, with a series of tangible "goals". No one on the bus was required to compromise their subjectivity to be part of a wider community, because as soon as that community had formed, it disappeared. In other words, the artwork's very interstice contains its own dissolution as part of its proposition and any transformation that the intervention brings about is located entirely within the subjectivity of the people who participate.

\section{Disconcerting situations}

I have argued that Teresa Siewerdt's intervention demonstrates how political art experiments can create ephemeral micro-utopias that are characterised by an absence of slogans and prescriptive understandings of community. In this space, people are free to elaborate their own subjectivity, and in this vein, create a particular and personal scheme of meaning. And it is pertaining to this idea of "community", and to what extent that community is necessarily based on a shared or unified sense of meaning, that a discussion surrounding dissonance, and how it is articulated can be productive.

In the article "Antagonism and relational aesthetics" (2004) and more widely the book "Artificial Hells" (2012), Claire Bishop argues that Bourriaud places so much emphasis on the facilitation of intersubjective relations, that he entirely leaves aside the bigger question of what kinds of relations are being created, and by whom. In this manner, Bishop implicitly calls into question the emancipatory potential of such a platform, arguing that relational art, for all its claims to horizontality, can in fact end up being nothing more than another exclusive art world sphere, where the only relations permitted are "fundamentally harmonious" as they are "addressed to a community of viewing subjects with something in common" (2004: 68). The notion of a homogeneous audience articulating notions of "democracy" is problematic for Bishop who instead puts forward her theory of "relational antagonism", premised on Ernest Laclau and 
Chantal Mouffe's (1985) discussion of agonism and subjectivity:

A fully functioning democratic society is not one in which all antagonisms have disappeared, but one in which new political frontiers are constantly being drawn and brought into debate - in other words, a democratic society is one in which relations of conflict are sustained, not erased. (Bishop 2004: 66)

Bishop argues that in much of the body of work that can be characterised by relational aesthetics, "the structure of the work circumscribes the outcome in advance" (2004: 68), despite these works' claims to open-endedness or participation.

This particularly situated debate points to reflections on conflict that are of significance more widely for both social movement politics and artistic interventions with activist connotations. The extent to which Bishop's critique of relational aesthetics is justified is not the subject of this article, but such a consideration, necessarily brief, does highlight two key points: first, Bishop's Lacanian emphasis on the concept of subjectivity as inherently fractured and decentred, and second, how these divergent subjectivities are to be articulated. To begin with, it is important to note that Bishop's depiction of the "homogenous relations" produced in Bourriaud's micro-utopia is at odds with Bourriaud's own emphasis on how art can emancipate diverse forms of subjectivity. As Bourriaud states: "Subjectivity does not stem from any homogeneity. On the contrary, it develops itself by cuts, segmenting and dismembering the illusory units of psychic life" (2002: 94).

"Harmony" is therefore not the goal of the relational aesthetic paradigm. In Siewerdt's intervention, despite the sense of "community" that was created on the bus, there was nothing homogenous about its membership. Bishop's critique of Rirkrit Tiravanija's performance, Untitled (Free), in which the artist served free curry from an ad hoc kitchen in an art gallery, is premised on the idea that only art "insiders" had access to the performance. This was clearly not the case for Jardim de Passagem. Indeed, the performance's very positioning within a transitory public/private space conferred an accessibility, but also an implicit reflexivity on notions of what it is to have access to certain spaces. Further, Bourriaud argues that the micro-utopia should not only be ephemeral, but also critical:

The subversive and critical function of contemporary art is now achieved in the invention of individual and collective vanishing lines, in those temporary and nomadic constructions whereby the artist models and disseminates disconcerting situations. (2002: 31, my emphasis)

The forceful articulation of dissonance is a central issue for Bishop and relational antagonism's seeks to differentiate itself through not seeking to smooth contours of difference from groups which are brought together by a work of art. Bishop puts forward the example of Santiago Sierra's $250 \mathrm{~cm}$ Line Tattooed on Six Paid People, in which the artist arranged six men in an art gallery in Havana, perceived to not belong to the "art world", and tattooed a line across their backs, creating an art work of $250 \mathrm{~cm}$ length. Echoing the questionable ethics of $\mathrm{Ai}$ Weiwei's recreation of a Syrian boy washed up on a beach, the work's foreclosed gesture finds resonance in Bishop's dismissive perspective on participatory art: "Destructive modes of participation might be more inclusive than those that purport to be democratically open" (2012: 49).

In this argument, Bishop contends that Sierra creates "dissonance" by "mobilising a tougher, more disruptive approach to 'relations"' (2004: 77), generating friction and discomfort, and thereby ultimately facilitating relations that are more "democratic". 
Leaving aside the debate as to whether "antagonism" necessarily reflects Mouffe's concept of agonistic pluralism (see Honig 1993, Adorno 1974, Connolly 1991), is it the case that the irritation, non-engagement, and lack of patience of passengers in Jardim de Passagem does not count as dissonance, merely because it is not articulated in such a forceful manner? I argue that the casual ill-feeling of the bus journey signals a gesture that is just as important in terms of poetic significance as tattooing a line across people's backs, or the herding of crowds across the Tate Modern's Turbine Hall. ${ }^{13}$ Indeed, the micro gestures of dissonance inherent to Jardim de Passagem, and the positioning of the intervention in such a public space, illustrate the subtle sense of détournement that is possible within a community which might superficially seem to display an "immanent togetherness". In this manner, the nuanced gestures of dissonance expressed by Jardim de Passagem passengers stand in productive contrast to the sharply framed ethical "controversy" generated by the works of artists such as Santiago Sierra. As I have noted above, for Maeckelbergh dimensions of conflict are central to the horizontal elaboration of subjectivity: "consensus" has come to be rejected through its associations with compromise and unanimity. However, how such dimensions of dissonance are expressed has signal implications for the elaboration of meaning. If, as Maeckelbergh argues, adversarial conflict is not caused by diversity, but rather by the delimitation of this diversity, then it follows that conflict can be productive if it is given space for expression. Although Siewerdt's intervention may seem outwardly harmonious, in fact it subtly engenders and indeed facilitates a type of dissonance which is constructive and not adversarial, in the very openness that it proposes for participants to offer a reaction. In aesthetic terms, this is realised through the fact that the intervention is less permanently scarring, recalling the example of Sierra, and more inherently disconcerting, in Bourriaud's vocabulary. Getting aboard a bus, to be confronted with a swaying, verdant, urban garden on one's way to work, offers a degree of the bizarre, which is only augmented by the continual growth of this green space, until it begins to encroach on one's very own personal space. It is this deliberate strangeness of Siewerdt's intervention, and its nonsensical juxtaposition of the subversive with objects as banal as pot plants and flowers, that creates a non-adversarial difference of opinion, offering a productive dissimilarity with the work of artists who Bishop cites as putting forward a relational antagonism.

Following Maeckelbergh therefore, in Sierra's tattooing of "unelite" people in an "elite" space to create an "antagonistic" provocation premised on a priori assumptions of class, I see an adversarial statement that can only obliterate meaning, rather than facilitate it. By contrast, in an analysis of Jardim de Passagem, it seems important to consider the full range of dissonant gestures and not just those of "monumental", easily documented, or even readily marketable interest: the shift from a frown to a smile, from non-engagement to an embrace through tears, represents a constructive conflict, signifiers of the multiplicity of subjectivity that underpins the possibilities of a more diverse society.

\section{Conclusion}

Whether pertaining to social movement politics or artistic interventions with activist connotations, meaning and how it is contested emerge as salient, pressing issues. The subjective

13 The cover of Claire Bishop's "Participatory Hells" depicts Tania Bruguera's Tatlin's Whisper \#5 at the Tate Modern. In this installation, visitors to the exhibition are subject to crowd control tactics, enforced by two mounted policemen. 
turn in social movement politics and the relational aesthetics paradigm both call for diverse subjectivities to be placed at the core of how we envision new worlds. Yet, from within both contemporary art worlds and organised mass mobilisation, a discourse premised on identity politics, seeking to pre-determine and essentialise identities to better present a "coherent" platform continues to be articulated.

Despite the compelling resonance between relational aesthetics and direct action politics there are important differences between projects like Jardim de Passagem and activists' political experiments. There are at least two productive vectors of differentiation in this sense, temporal, and more controversially, "pragmatic". Jardim de Passagem proposes an ephemeral intervention, but it is unclear on which plane of temporality the artist seeks to provoke change. Is this change designed to reside exclusively in the moment of its happening, or are these gestures designed to provoke a longer term shift? This doubt could be put into contrast with two examples: First, Situationist International's focus on the gift as a long term revolutionary strategy, articulated through the distribution of a magazine entitled Potlatch in order to subvert commodity exchange by transforming commodities into gifts (Martin 2012: 134); or second, the "Free Store" as described in Razsa's ethnography of direct action politics (2015) where goods are given away in public rather than exchanged for cash as a way to prefigure different social relationships among urban dwellers that will exist beyond the moment of exchange. Does the ephemerality of Siewerdt's intervention preclude it from the longer-term ambitions of these two examples? Do we accept indeed that ephemeral moments cannot articulate long-term change? As Bourriaud pointedly remarks, demonstration is charged with a temporal import in and of itself, and relations can constitute "a formal resolution which touches on eternity precisely because it is specific and temporary" (2002: 54, my emphasis). In this manner, while Jardim de Passagem may not have achieved anything "quantifiably long term", I suggest that in artistic interventions with activist connotations, just as in social movement politics, subtle and ephemeral gestures of conflict may signify greater long-term import than the "radical" and destructive in bringing about lasting change.

However, in terms of what we can understand as a more "pragmatic" vector, there is a clear differentiation that needs to be made regarding the "production" of subjectivity. Among certain radical activists, seizing the means of subject-making is not an end in itself, but rather a means through which to produce subjects who are prepared to challenge the conditions of their exploitation and alienation in contemporary social orders. While this description could certainly be applied to the Landless Workers'Movement, it could not be used to describe an intervention like Jardim de Passagem. With Jonas Tinius, I have argued that what exists in the micro-utopia, beyond dimensions of conviviality, is an ethico-aesthetic proposition for how to live your life with others: a call to horizontality and reflection, premised on the transitive ethic between the artist and a community of participants (Flynn and Tinius 2015). There is a non-negotiable difference between a process that is seeks to create meaning through reflection, and one that more actively seeks to impart meaning to a subject. If art really is the looking-glass to the future, then a focus on the germinal and open-ended is required: it is only in engaging with its poietic and horizontal matrix of sociality that we can discern what will happen next. 


\section{References}

Adorno, T. 1974, Minima Moralia. London: Verso Editions.

Arendt, H. 1951. The Origins of Totalitarianism. New York: Harcourt, Brace and Co.

Asante, M. K. 2009. It's Bigger Than Hip Hop. New York: St. Martin's Press.

Bishop, C. 2004. Antagonism and relational aesthetics. October 110: 51-79. .2012. Artificial Hells: Participatory Art and the Politics of Spectatorship. London: Verso.

Bourriaud, N. 2002. Relational aesthetics. Dijon: Presses du Réel.

Brodwin, P. 2003. "Marginality and Subjectivity in the Haitian Diaspora". Anthropological Quarterly 76(3): 383-410.

Caldeira, T. 2001. Crime, Segregation, and Citizenship in São Paulo. Oakland, University of California Press.

Chaves, C. 2000. A Marcha Nacional dos Sem-terra: Um Estudo Sobre a Fabricação do Social. Rio de Janeiro: Relume Dumará.

Connolly, W. 1991. Identity/Difference: Democratic Negotiations of Political Paradox. London: Cornell University Press.

Das, V. "Violence, Gender, and Subjectivity". Annual Review of Anthropology 37: 283-299.

Dossin, C. 2015. The Rise and Fall of American Art, 1940s-1980s: A Geopolitics of Western Art Worlds. Farnham: Ashgate.

Elkins, J. 1996. The Object Stares Back: On the Nature of Seeing. New York: Simon and Schuster.

Escobar, A. 2014. Territories of Difference: Place, Movements, Life, Redes. Durham: Duke University Press.

Evans, M. 2015. Artwash: Big Oil and the Arts. London: Pluto Press.

Farrington, K. 2013. "The Failure of Aesthetics in the Occupy Movement, seen through the lens of the 7th Berlin Biennale". Artcore 1(2): online.

Flynn, A. and Tinius, J. (eds.). 2015. Anthropology, Theatre, and Development: The transformative potential of performance. London: Palgrave. . 2013. 'Mística, Myself and I: Beyond Cultural Politics in Brazil's Landless Workers' Movement”. Critique of Anthropology. 33(2): 168-192.

. 2015. "Re-imagining Political Subjectivities: Relationality, Reflexivity, and Performance in Rural Brazil" in Flynn, A. and Tinius, J., Anthropology, Theatre and Development: The transformative potential of performance. London: Palgrave Macmillan.

García Canclini, N. Art beyond itself: Anthropology for a Society without a Story Line. Durham, NC: Duke University Press.

Guattari, F. 1995. Chaosmosis: an ethico-aesthetic paradigm. Bloomington: Indiana University Press.

Hammond, J. L. 2014. "Mística, meaning and popular education in the Brazilian Landless Workers Movement1”. Interface: A Journal on Social Movements, 6(1): 372 - 391.

Honig, B. 1993. Political Theory and the Displacement of Politics. Political Theory and the Displacement of Politics. Ithaca, N.Y.: Cornell University Press.

Issa, D. 2007. Praxis of Empowerment: Mistica and Mobilization in Brazil's Landless Rural Workers' Movement. Latin American Perspectives. 34(2): 124-138.

Jean-Klein, I. 2000. "Mothercraft, Statecraft, and Subjectivity in the Palestinian intifada". American Ethnologist 27(1): 100-127.

Juris, J. 2008. Networking futures: The movements against corporate globalization. Durham, NC: Duke University Press.

Kester, G. 2015. Editorial. FIELD 1(1): 1-10. 
Kompatsiaris, P. 2014. "Curating Resistances: Ambivalences and Potentials of Contemporary Art Biennials”. Communication, Culture \& Critique, 7(1): 76-91.

Kriesi, H. 1996. "The organizational structure of new social movements in a political context" in McAdam, D., McCarthy, J., and Zald, M., editors. Comparative perspectives on social movements: Political opportunities, mobilizing structures, and cultural framings. Cambridge: Cambridge University Press. pp. 152-184.

Laclau, E. and Mouffe, C. 1985. Hegemony and Socialist Strategy: Towards a Radical Democratic Politics. London: Verso.

Lebel, R. 1959. Marcel Duchamp. New York: Paragraphic Books.

Leone, M. 2013. Signs of the Soul: Toward a Semiotics of Religious Subjectivity Signs and Society 1(1): $115-159$.

Maeckelbergh, M. 2009. The Will of the Many: How the alterglobalisation movement is changing the face of democracy. London: Pluto Press.

Martin, K.2012. "The 'potlatch of destruction': Gifting against the state." Critique of Anthropology 32(2):125-142.

O'Sullivan, S. 2012. On the Production of Subjectivity: Five Diagrams of the Finite-Infinite Relation. London: Palgrave Macmillan.

Olson Jr., M. 1965. "The Logic of Collective Action: Public Goods and the Theory of Groups". Harvard Econ. Stud.,Vol. 124. Cambridge, MA: Harvard University Press.

Park, R. 1967. “On Social Control and Collective Behavior," in Turner, R. (ed.) Selected Papers. Chicago: University of Chicago Press.

Razsa, M. 2015. Bastards of Utopia: Living radical politics after socialism. Bloomington: Indiana University Press.

Tarlau, R. 2013. "Soviets in the countryside: The MST's remaking of socialist educational practices in Brazil," in Griffiths, T. and Millei, Z. (eds.), Logics of Socialist Education: Engaging with Crisis, Insecurity and Uncertainty. London: Springer. Pp. 53-72).

Sandoval, C. and Latorre, G. 2007. "Chicana/o Artivism: Judy Baca's Digital Work with Youth of Color," in Everett, A (ed.) Learning Race and Ethnicity: Youth and Digital Media. Cambridge, MA: MIT Press.

Snow, D., Rochford Jr, E., Worden, S., and Benford, R. 1986. "Frame alignment processes, micromobilization, and movement participation”. American Sociological Review 51(4): 464-481.

Tilly, Charles. 2008. Social Movements, 1768-2004. Cambridge: Cambridge University Press.

Touraine, A. 1988. Return of the Actor: Social Theory in Postindustrial Society. Minneapolis: University of Minneapolis Press.

Wolford, Wendy. 2003. "Producing Community: The MST and Land Reform Settlements in Brazil". Journal of Agrarian Change. 3(4): 500-520. 